\title{
静岡県沼津市戸田の自生タチバナ群落の多様性解析とその維持機構の推定
}

\author{
清水徳朗 ${ }^{*}$ ・長倉建治 ${ }^{2,3}$ ・奥田董樹 2,3 ・稲木博文 ${ }^{3}$ ・奥田 勇 ${ }^{3,4}$ ・遠藤重由 ${ }^{5}$ \\ ${ }^{1}$ 農業・食品産業技術総合研究機構果樹茶研究部門カンキッ研究領域 $422-8092$ 静岡市清水区 \\ 2 戸田森林組合 410-3402 静岡県沼津市戸田 \\ 3 戸田タチバナの会 410-3402 静岡県沼津市戸田 \\ ${ }^{4}$ 井田神社総代 410-3401 静岡県沼津市井田 \\ 5 沼津市役所 410-8601＼cjkstart静岡県沼津市御幸町
}

\section{Evaluation of Genetic Diversity in Wild Tachibana Population of Heda, Shizuoka, Using DNA Marker Analysis, and Stable Maintenance of the Population}

\author{
Tokurou Shimizu ${ }^{1 *}$, Kenji Nagakura ${ }^{2,3}$, Masaki Okuda ${ }^{2,3}$, Hirofumi Inagi ${ }^{3}$, \\ Isamu Okuda ${ }^{3,4}$ and Shigeyoshi Endo ${ }^{5}$ \\ ${ }^{I}$ Institute of Fruit Tree and Tea Science, NARO, Shimizu, Shizuoka 424-0292 \\ ${ }^{2}$ Heda Forestry Cooperative, Numazu, Shizuoka 410-3402 \\ ${ }^{3}$ Heda Tachibana Club, Numazu, Shizuoka 410-3402 \\ ${ }^{4}$ Ida Shrine, Numazu, Shizuoka 410-3401 \\ ${ }^{5}$ Numazu City Hall, Numazu, Shizuoka 410-8601
}

\begin{abstract}
Tachibana (Citrus tachibana (Makino) Tanaka) is a citrus species indigenous to Japan. It has been known since before the Nara period ( $\sim 800 \mathrm{AD}$ ), and several wild populations are present in forests along the Pacific coast, from Tokai to Kyushu Island. Although tachibana was previously regarded as consisting of a single genotype, recent research with DNA markers suggested there are at least three different genotypes. Previous work was carried out across different wild populations, but little is known about the genetic diversity within each population, or among populations. In this study, wild tachibana trees of a population in Heda, Shizuoka ( $\mathrm{n}=64 ; 24$ in Ida area and 40 in Kamiya area) were sampled to explore the population's genetic diversity and promote utilization and conservation. Using DNA marker analysis for both nuclear and organelle genomes, we confirmed that, in total, 60 plants (22 in Ida and 38 in Kamiya) had a tachibana-A strain genotype. Four unidentified citrus plants in the sample were genotyped as Natsudaidai (C. natsudaidai Hayata). No selfed or hybrid offspring were found in either area. The observations suggest that it may be difficult to obtain hybrids from tachibana-A as seed parents, and another DNA marker analysis of open-pollinated seeds showed similar results. The survey revealed several young tachibana trees in the population, and we suggest that vegetative propagation by polyembryonic seeds may facilitate asexual maintenance of this tachibana population.
\end{abstract}

Key Words : Citrus, DNA marker, genetic diversity, nucellar seedling, plant population キーワード：DNA マーカー，群落，遺伝的多様性，カンキッ，珠心肧実生

\section{緒言 \\ タチバナ (滳) は古くから日本国内に存在したカンキツ} 種の一つで, 葉腋に $5 \mathrm{~mm}$ ほどの棘を有し, 果実は横径 $3 \mathrm{~cm}$ 程度で種子は多胚である。果実は 11 月頃から着色を 開始し，果皮，果肉ともに橙色を呈する。果皮は薄く，比 較的なめらかであるが，着色開始と並行して浮皮が進行 し，年末にはほぼすべての果実が浮皮となるため，剥皮は 容易である。花は甘く強い芳香を持ち，葉にも他の寛皮性 カンキッにはみられない香気が感じられる（吉武, 2008).

2019 年 7 月 23 日 受付. 2019年 9 月 26 日 受理.

* Corresponding author. E-mail: tshimizu@affrc.go.jp
果実も好ましい芳香を備えているが，果肉は酸含量が高 く, 多くの種子を含み, 可食部が少ないため経済栽培は行 われていない. 国内では静岡県東部から愛知県, 三重県, 高知県, 愛媛県, 宮崎県の温暖な太平洋岸沿いの急傾斜地 に野生タチバナの自生地が知られて扣り，沼津市戸田に自 生するタチバナは, 現在国内に存在するタチバナの北限と して知られている. しかしタチバナは個体数の減少や生育 条件の悪化などが懸念され，環境省レッドリストでは存続 基盤が脆弱で生育条件の変化によっては絶滅危惧に移行す る可能性のある「準絶滅危惧 (NT)」に分類されている（環 境省, 2019)

Tanaka（1954）や Swingle（1967）は，タチバナを古くか ら日本に自生する寛皮性カンキッの1つとみなし, Citrus 
tachibana (Makino) Tanakaの学名を付与した. 日本書紀に 記述のある, 田道間守が西暦 70 年に常世国から持ち帰っ たとされる「非時香菓（ときじくのかぐのこのみ）」がタ チバナであるとされて扮り, 延喜式（927年）には駿河国 や相模国から「滳皮」が朝廷に献上されたとの記述もある. 一方，牧野（1955）や田中（1926）らは，田道間守が持ち 帰ってきたものはキシュウミカンもしくはダイダイであっ たとする説を唱えている。 このように，タチバナは古くか ら知られていたにもかかわらず，「常世国」から持ち帰っ たとされる時期やその後の国内の伝達過程だけでなく，そ もそもタチバナがぞこからもたらされてきたのかといら根 源的な問いは現在も解決を得て抒らず，多くは特性の記述 にとどまってきた。

井手ら（1989）は1987年から 1988 年にかけて日本国内 の野生果樹自生地の分布状況に関する包括的な調查を実施 し，この中で日本各地のタチバナについても詳しく取り上 げた。この調査の過程で, Hiraiら（1990）は静岡県伊豆半 島から宮崎県の南部までの 19 地点でタチバナ遺伝資源 113 点を収集し，アイソザイム分析からそれらが 4 つのア イソタイプに分類されることを示し, さらに高知県土佐清 水々宮崎県石波海岸の 2 地点ではタチバナ群落内に $2 つ 0$ アイソタイプが存在することを報告した。 この研究は，そ れまでの形態的特徵に基づく品種同定から分子マーカーに 基づくタチバナ同定への端緒となったが，当時分析に使用 されたアイソザイムは 3 つので，4つのアイソタイプ間 の関係性や群落内の多様性は不明であった.

タチバナを含む，現在知られているカンキッ種が多様性 を拡大した過程の詳細は長らく不明であったが，清水らは 高精度 DNA マーカー解析に基づき，キシュウミカン，タ チバナ，ユズ，コウジ，ダイダイやクネンボなぞの少数の 基幹品種が交配を繰り返していくことで徐々に多様化した ことを具体的に示した（Shimizu ら，2016b，2019）。また， 国内のタチバナには3つの遺伝的に異なる系統（タチバ ナ-A，タチバナ-B，タチバナ-C）が存在することを報告す るとともに，核ゲノムと細胞質ゲノムの比較から，これら 3つの系統は親が共通の同祖系統である可能性も示唆した (Shimizu ら，2016b)。さらに，各系統の後代品種として花 柚（ハナユ，C. hanayu Sieb. ex Shirai ; ユズ×タチバナ-A), ギリミカン (C. tardiva hort. ex Shirai; 不明品種 $\times$ タチバ ナ-B)，ヒュウガナッ (C. tamurana hort. ex Tanaka ; 不明品 種×タチバナ $-\mathrm{B})$, オウゴンカン $(C . \mathrm{spp}$. ; 不明品種 $\times$ タ チバナ-C）を見いだし，タチバナがカンキッ在来種の遺伝 的多様性に重要な役割を果たしてきたことがはじめて確認 された。

このよらな研究とは別に, カンキッ在来品種のゲノム解 析と品種間多型の相同性に基づく進化論的研究から, カン キッ類は今から約 900 万年前の中新世後期に現在のカン キッ属の祖先植物がカラタチ属と分化し，その後 800 万〜 600 万年前にかけて現在のカンキッ栽培品種の祖先種を含
む10 種が分化したと推定されている（Wuら，2018）。そ のらち，マンダリンとシトロン，ブンタンの3つを主な基 本祖先種として，それらが交雑を繰り返すことで多くの栽 培種が生久出されたとされる（Wu ら，2018）。祖先種と なったマンダリンはブンタン祖先種と交雑することでブン タンのゲノムが徐々に移入され，それがマンダリンやブン タンとさらに交雑を繰り返すことでポンカンやスイートオ レンジ，クネンボ， ウンシュウミカン，グレープフルーッ やクレメンティンなどの主要な栽培種が生み出されたと考 えられている. ゲノムレベルの解析から, タチバナは, ブンタンなど他の祖先種に由来するゲノムを棌とんど含ま ない，現在残っている最も起源の古いマンダリンの 1 種と された（Wu ら，2018）。一方，Tanaka（1931）は台湾の山 岳地帯にも野生タチバナが存在することを報告している が，これが日本のタチバナと同一であるかどうかは確認さ れて打らず，現在知られている 3 系統のタチバナとの関連 も不明である. 祖先種の 1 つとてのタチバナの遺伝的多 様性を解明することは，日本国内へのタチバナとカンキッ の伝来過程やタチバナ系統とカンキッ類の多様性拡大の過 程を考察するための重要な知見となる。ささらに，国内の夕 チバナ自生地には未同定のタチバナ系統やその後代個体が 残されている可能性もある。

国内の自生地のうち，日本最北部に存在する静岡県戸田 村（当時）のタチバナについて，井手ら（1989）は現地の 山林は溶岩のために植林に適さず，主に $30 \sim 40$ 年の周期 でクヌギ薪炭林として利用されてきたこと，その際にタチ バナも良質な炭材として他の樹と同様に伐採・再生させて いたと報告している．関係者への聞き取りから，同地は第 二次世界大戦までは人為的な伐採を受けつつもその後は伐 採なぞは行われていないことから，自生のタチバナが長期 間に渡り個体と群落を維持してきた機構を推定すること で，国内のタチバナの多様性や伝搬を理解するだけでな く，今後現地の保全を図るらえでも多くの示唆が得られる ものと期待される。 そこで本研究では，Hiraiら（1990）が 調査したタチバナ自生地のうち, 静岡県沼津市の 2 か所に 自生するタチバナに注目し，自生地内の全個体を対象に高 精度 DNA マーカー分析を実施し，遺伝的多様性の把握と 自生地内での群落の維持機構，および，戸田にタチバナが もたらされた経緯を考察することを目的とした。

\section{材料および方法}

\section{1. 植物材料}

本研究では, 静岡県沼津市戸田（旧戸田村）の 2 か所の タチバナ自生地（紙谷地区拉よび井田地区，第 1 図）にお いて維持されているタチバナ樹を対象とした．現地の状況 を確認するため，まず 2012 年 12 月 13 日に紙谷地区を，ま た2 017 年 6 月 30 日に井田地区をそれぞれ予備調査して対 象樹の植生場所と樹高，樹勢を調査した，確認できた樹は 主幹をテープで標識した。分析用の試料採取は 2017 年 7 


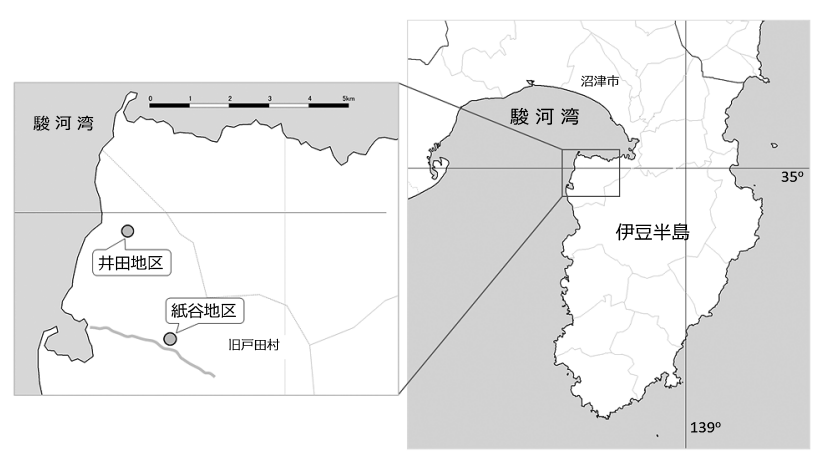

第 1 図 静岡県沼津市戸田のタチバナ自生地

月 31 日と 2017 年 12 月 7 日の 2 回に分けて行った. 2017 年 7 月 31 日の試料採取では予備調査の情報をもとに個体 を確認し，春枝に着生している健全な生葉を採取して分析 試料として持ち帰った。 2017 年 12 月 7 日の試料採取では, 初回の調査で見落とされていたものを追加採取して初回と 同様に生葉を採取するとともに，着生果実を一部採取して その重量を計測した。採取した生葉はShimizuら（2016a） の方法に従い $100 \mathrm{mg}$ を凍結して振盪破砕し，0.1\%ポリビ ニルピロリドンを含む $50 \mathrm{mM}$ トリス緩衝液（pH 8.0）で数 回洗浄後, Nucleon Phytopureキット（GEヘルスケアジャ パン(株)）でDNAを抽出した。得られたDNA はリボヌク レアーゼ処理でRNAを分解後, フェノール・クロロホ ルム抽出し, DNAをエタノール沈殿で回収した。得られ た DNA は少量の $1 \times$ TE $0.2(10 \mathrm{mM}$ トリス塩酸緩衝液, 0.2 mM EDTA, pH 8.0) 溶液に溶解し, Qubitアッセイ (サーモフィッシャーサイエンティフィック(株)）で定量 して一定濃度に調整した.

2. Simple sequence repeat (SSR) マーカー遺伝子型分析 核ゲノムの遺伝子型分析には，Shimizu ら（2016b）が報 告したカンキッのSSRマーカーから, 判別性が高く, か
第 2 表 解析に供試したオルガネラ SSR マーカー

\begin{tabular}{lll}
\hline \hline 葉緑体ゲノムSSR マーカー & CSS03 & ccmp 2.2 \\
& CSS04 & ccmp 6.2 \\
& CSL01 & ccmp 7.2 \\
& CSL09 & ccmp 10.2 \\
\hline ミトコンドリアゲノムSSRマーカー & rrn5/rrn 18-1 & \\
& nad2/4-3 & \\
& nad7/1-2 & \\
\hline
\end{tabular}

つ複数の既知の親子品種間で遺伝子型に矛盾がないものの らち, タチバナでへテロ遺伝子型となるものを中心に 76 マーカーを選定した (第 1 表). 核ゲノムの SSR マーカー 分析は, Shimizu・Yano（2011）抽よ゙ Shimizuら（2016b） の方法に従い， $5 \mathrm{ng}$ の全 DNA をPCR 増幅し，その後 barcoded split tag（BStag）を用いる蛍光マルチプレックスポ ストラベル法で 4 マーカーずつ同時に蛍光標識した. 蛍 光標識後, 反応液を 2 倍希釈して GeneScan 600LIZ（サー モフィッシャーサイエンティフィック(株)）を添加し， ホルムアミドで $95^{\circ} \mathrm{C}, 4$ 分間加熱変性後, DNA シーケン サ (ABI 3130xl, POP-7, $36 \mathrm{~cm}$ キャピラリ, サーモフィッ シャーサイエンティフィック(株)) で泳動した。細胞質の 遺伝子型分析には，Shimizu ら（2016b）が報告した葉緑体 ゲノム用 SSR マーカー 8 種, およびミトコンドリアゲノム 用 SSR マーカー 3 種（第 2 表）を使用し，核ゲノムの遺伝 子型分析と同様の方法で分析した.

\section{3. 遺伝子型データ解析}

核およびオルガネラゲノムの遺伝子型解析には GeneMapper 4.0（サーモフィッシャーサイエンティフィッ ク(株)）を使用し，泳動結果をサイズコール後，各マー カー, サンプルのアリルをコールした．分析対照には，農 研機構果樹茶部門カンキッ研究領域内で保存している, 遺

第1表 解析に供試した SSR マーカー

\begin{tabular}{|c|c|c|c|c|}
\hline CiBE0246.1 & CTVR01.1 & CUBER410.1 & CUBER918.1 & CUBER925.1 \\
\hline CX2004. $2^{\mathrm{z}}$ & CX3005.1 & CX5019.3 & CX6037.3 & F02.2 \\
\hline GRW3011.1 & GSR10S17.1 & GSR10S29.1 & GSR3121.1 & GSR3136.1 \\
\hline GSR6101.1 & GSR6133.1 & NSX118.1 & NSX121.1 & NSX132.1 \\
\hline NSX145.1 & NSX153.1 & NSX156.1 ${ }^{z}$ & NSX161.1 & NSX165.1 \\
\hline NSX187.1 & NSX82.1 & SRPE02.1 & SRPE05.1 & SSR07A05.3 \\
\hline SSR07A07.2 & SSR07A20.1 & SSR07A21.3 & SSR07A24. $3^{\mathrm{z}}$ & SSR07B05.1 \\
\hline SSR08A06.2 & SSR08A07.2 & SSR08A09.2 & SSR08A14.2 & SSR08A $16.2^{z}$ \\
\hline SSR08B05.2 & SSR08B15.2 ${ }^{z}$ & SSR08B21.2 & SSR08B25.2 & SSR08B29. $2^{z}$ \\
\hline SSR08B31.2 & SSR08B40.2 & SSR08B54.2 & SSR08B60.1 & SSR08B64.1 \\
\hline SSR08B78.1 & SSR08B82.1 ${ }^{\mathrm{z}}$ & SSR08B85.2 & SSR08B88.2 & SSR08B92.2 \\
\hline SSR08C05.1 & SSR11A06.1 & SSR11A27.1 ${ }^{z}$ & TSGR264.1 & TSGR265.1 \\
\hline TSR8EM24.2 & TSRA101.1 & TSRA107.1 & TSRB09. $2^{z}$ & TSRB11. $2^{\mathrm{z}}$ \\
\hline TSRB39.2 & TSRF101.1 & TSRF157.1 & TSRF162.1 & TSRF164.1 \\
\hline TSRF195.1 & TSRF211.1 & TSRF229.1 $1^{z}$ & TSRF234. $1^{\mathrm{z}}$ & TSRF237.1 \\
\hline TSRP07. $2^{z}$ & & & & \\
\hline
\end{tabular}

z タチバナ-A 種子の交雑胚検定に供試した SSR マーカー 
第3 表 供試した対照品種一覧

\begin{tabular}{llc}
\hline \hline 品種・系統名 & \multicolumn{1}{c}{ 学名 } & アクセッション ID \\
\hline タチバナ-A & Citrus tachibana (Makino) Tanaka & 168872 \\
タチバナ-B & C. tachibana (Makino) Tanaka & 117880 \\
タチバナ-C & C. tachibana (Makino) Tanaka & 117882 \\
ハナュ & C. hanaju Siebold ex Shirai (ユズ×タチバナ-A) & 117378 \\
ギリミカン & C. tardiva hort. ex Shirai (不明品種×タチバナ-B) & 117404 \\
ヒュウガナッ & C. tamurana hort. ex Tanaka (不明品種×タチバナ-B) & 117317 \\
オウゴンカン & C. spp (不明品種×タチバナ-C) & 172148 \\
\hline
\end{tabular}

伝子型が既知のタチバナ 3 系統（タチバナ-A，-B 拈よび -C）とその後代品種（ハナュ，ギリミカン，ヒュウガナッ， 招よびオウゴンカン) を供試した（第3表），得られた遺 伝子型をもとに，同時に分析した対照品種との遺伝子型の 一致を確認するとともに，遺伝子型が既知の在来品種 101 点（Shimizu ら, 2016b）との同一性を検証した.

\section{4. 自然交雑種子の交雑胚の検証}

農研機構果樹茶研究部門カンキッ研究領域 (静岡市清 水区）に植栽されているタチバナ-A（ID 168872）の放任受 粉樹より採取した果実を利用した。胚数の調査には，9月 初めに採取した果実から取り出した，十分に成長している 未熟種子を 20 粒供試した。発芽試験には 1 月に採取した 果実から取り出した完全種子を供試した。種子をジフィー セブン $\left(42 \mathrm{~mm}\right.$ ，(株) サカタのタネ）に置床し， $28^{\circ} \mathrm{C}, 16$ 時 間明 $/ 8$ 時間暗環境下で維持して発芽させた。 1 か月後に 発芽したものの割合を発芽率として求め, 発芽種子当たり の新梢数を発芽平均新梢数, 扣よび，その長さを新梢長 とした，発芽した各新梢は次に示す簡易 DNA マーカー分 析に供試した。展開した第 3 葉から約 $1 \mathrm{~mm}^{2}$ の葉片をカミ ソリで切り出し，マイクロチューブに分注した $100 \mu \mathrm{L} の$ CS25 混合液 $(6 \%(\mathrm{w} / \mathrm{v})$ Chelex-100（Bio-Rad)，4\%（w/v） Sephadex G-25 Fine（GEヘルスケアジャパン(株) を含む $50 \mathrm{mM}$ Tris- $\mathrm{HCl}, \mathrm{pH}$ 8.0) 中に浸した. ペレットペッスル (1.5 mL，サーモフィッシャーサイエンティフィック(株) ) を用いて室温で手早く葉片を磨砕し，蓋をして 10 秒間振 盪擋拌後, $100^{\circ} \mathrm{C}, 5$ 分間加温し, その後水上に 1 分間放 置した. 10 秒間再度振盪摚拌し，氷上で 5 分間静置して から $4^{\circ} \mathrm{C} て ゙ ~ 10,000 \times \mathrm{g}, 5$ 分間遠心し，上清を新しいチュー ブに回収してそのらち $0.5 \mu \mathrm{L}$ SSR マーカー分析に使用 した。分析には選抜した 24 種のSSR マーカー（第 1 表） を供試し, Shimizuら（2016b）の方法に従い，始めの PCR を 38 サイクルに変更して行った。

\section{5. データ解析}

データ解析にはR（ver. 3.61; https://www.r-project.org/) 抒よびRStudio（Version 1.2.1335； https://www.rstudio.com/） を使用した。 グラフ作成には R の ggplot2 パッケージを使 用し，有意差検定には ggsignif パッケージの wilcox.test を 利用した。

\section{結果}

\section{1. 静岡県戸田地区におけるタチバナの自生状況と分析試 料の採取}

本研究では, 静岡県沼津市戸田 (2005 年 4 月 1 日の沼 津市との合併前は静岡県戸田村）の紙谷地区（北緯 $34^{\circ} 58.08 .9$, 東経 $138^{\circ} 48.08 .8$, 標高 $125 \mathrm{~m}$ ) と井田地区（北 緯 $34^{\circ} 59.56 .0$ ，東経 $138^{\circ} 47.04 .4 ＼mathrm{~ ， 標 高 ~} 29 \mathrm{~m} ）$ の 2 か所で採 取したタチバナを対象とした（第 1 図）。紙谷地区の自生 地は戸田大川沿いの静岡県道 18 号線脇から急峻な崖を $100 \sim 200 \mathrm{~m}$ 汪ぞ登った山林内にあり，現地は火成岩を含 む火山灰土壤や溶岩を主体としてクヌギなどの落葉樹が林 床を形成する急傾斜地である(第2図)。2012年および 2017年の現地調査では, 井手ら（1989）の報告と同様の, 露出した岩盤付近や傾斜変換線上に分布している 37 樹 を確認した．各樹の生育場所は高木の樹冠下で直達光が乏 しく，立地危険のために樹高を調査できなかった 1 樹を除 き, 調查時点で樹高が $4 \mathrm{~m}$ 以上のものが 20 樹認められた (第 4 表)。一方，群落内には樹高が $1 \mathrm{~m}$ 以下の若木も 3 樹 確認された。2017年 8 月の再調査では 2012 年に確認した 37 樹のらち 2 樹が枯死していたため対象外とし，それと は別に 2 樹を新たに確認してラベルを付け，分析用試料を 採取した。調査時に樹姿や葉の性状から，タチバナとは異 なるカンキッ樹も複数認めたが，これらがタチバナの自然 交雑実生である可能性を考慮し，調査対象地域内で確認さ れたカンキッ樹すべてを採取して以後の解析対象とした.

戸田紙谷地区では，タチバナの穂木採取用として利用さ れている，自生地で採取した種子に由来する実生樹（樹高 約 $5 \mathrm{~m}$ ）が同地区内の民家にあり，この樹からも試料を合 わせて採取した。ささらに 2017 年 12 月にも追加の現地調査 を行い，その際にラベルのついていない新たなカンキッを 3 樹確認した。自生地内の落葉樹はほほ落葉して扮り, 常 緑樹の確認は容易であった。これらについても試料を採取 し，合計で 42 点の試料を紙谷地区で採取した。採取時の 株元の観察から，これらはいずれも実生であることを確認 した。 もら 1 つの自生地である井田地区は，紙谷地区から 北西方向に直線距離で約 $3.6 \mathrm{~km}$ 離孔た井田神社の東側に 位置する (第 1 図)。現地は細かな起伏のある平坦地で, 

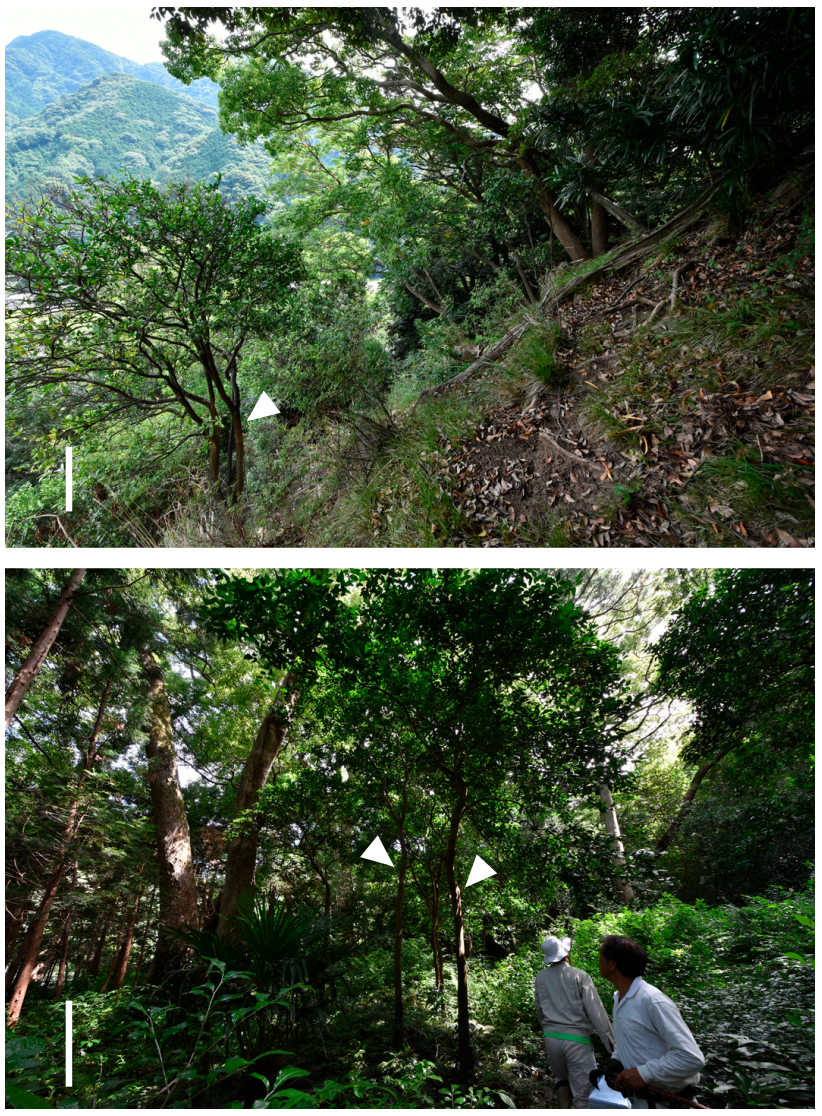

第 2 図 静岡県沼津市戸田自生地におけるタチバナの生育環境 上 : 紙谷地区, 下 : 井田地区

調査対象のタチバナ樹を白三角形で示す バーは約 $1 \mathrm{~m}$ に相当

上部は樹高 $10 \mathrm{~m}$ 以上の高木が密生し，林床は灌木や草で 被覆されている。時期や経緯については不明であるが, Hirai ら（1990）は井田地区のものが人為的に移植されて管 理されたものであるとしており，関係者への聞き取りでも 同様であった. 2017 年 6 月の調査時点で 20 本のカンキッ 樹を確認し，いずれも実生であった。このらち樹高が $4 \mathrm{~m}$ 以下のものは計 4 樹で $2 \mathrm{~m}$ 以下の若木も 1 樹確認されたが, 現地は直達光の乏しい低日射量環境のため, 樹高が $6 \mathrm{~m}$ を 超えるものが 14 樹と徒長した個体が多かった. 2017 年 7 月 31 日採取時点でも 20 樹を確認し, すべての個体から試 料を採取した.

これとは別に, 井田神社前の市道沿いの石垣に沿って 人為的に植えられたタチバナの接木樹が 5 樹確認された. 現地関係者への聞き取りから，詳しい経緯は不明であるも のの，紙谷地区から持ち込まれたと言われており，2地区 間で遺伝子型が共通する個体の有無を確認して人為的な 関与の可能性を検証するために，こちらについても合わせ て採取した。 2017 年 12 月の現地調査の際に，未標識の新 たなカンキッ若木を 1 樹確認し, 最終的に計 26 樹を井田 地区で収集した。 2017 年 12 月に着果状況についても調査 するとともに一部の果実を収集し，紙谷内区では対象とし
第4 表 収集したタチバナ樹の樹高分布

\begin{tabular}{lcc}
\hline \hline 樹高 & 紙谷地区 $^{\mathrm{z}}$ & 井田地区 $^{\mathrm{y}}$ \\
\hline$<1 \mathrm{~m}$ & 3 & 0 \\
$1 \sim 2 \mathrm{~m}$ & 3 & 1 \\
$2 \sim 4 \mathrm{~m}$ & 11 & 3 \\
$4 \sim 6 \mathrm{~m}$ & 16 & 2 \\
$6 \sim 8 \mathrm{~m}$ & 3 & 11 \\
$>8 \mathrm{~m}$ & 0 & 3 \\
未調査 & 1 & 0 \\
\hline 計樹本数 & 37 & 20 \\
\hline
\end{tabular}

$\mathrm{z}$ 調査時期 : 2012 年 12 月 13 日

$y$ 調査時期 : 2017 年 6 月 30 日
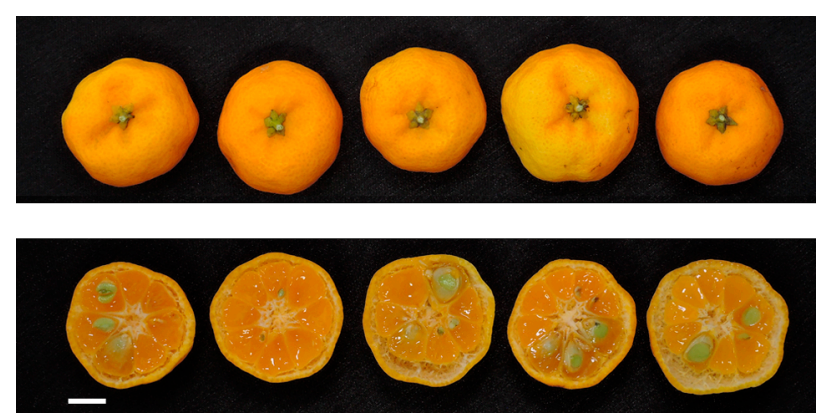

第3 図タチバナ-A の果実外観と赤道部切断面 農研機構果樹茶研究部門カンキッ研究領域（静岡市清 水区）に植栽されているタチバナ-Aの果実 バーは $1 \mathrm{~cm}$ を示す

た 42 点中 24 点（うち 1 点は同地区の民家のもの）, 井田 地区で対象とした 26 点中 20 点（うち外周の接木樹は 4 点） で果実の着生を確認し，合計でそれぞれ456点および 333 点の果実を収集した。果実の形態は農研機構果樹茶研究 部門カンキッ研究領域に植栽されているタチバナ-Aのも のと同じであったが (第 3 図)，収集した果実の平均重は $9.6 \pm 2.6 \mathrm{~g}$ (紙谷地区) と $10.6 \pm 2.3 \mathrm{~g}$ (井田地区) で，紙谷地 区のものが井田地区のものよりもやや小さい傾向が認めら れた (第 4 図).

\section{2. 遺伝子型の比較解析}

紙谷地区で収集した 42 点，および，井田地区で収集し た 26 点（うち 5 点が接木樹），計 68 点の核ゲノム遺伝子 型を，76のSSR マーカーで評価した。同時に分析した既 知のタチバナ-A, タチバナ-B, タチバナ-Cとの比較から, 紙谷地区で収集した 39 点（2017年 12 月に追加採取した 3 点を含む）と，対照として収集した紙谷地区の民家のタ チバナ樹 1 点の計 40 点はいずれもタチバナ-A とすべての SSR マーカーで遺伝子型が一致した。これらのオルガネラ ゲノムの遺伝子型分析結果もタチバナ-A と同じタチバナ 型と完全に一致したことから，これらはすべてタチバナ -Aであると結論づけた（第 5 表）。井田地区で収集したタ チバナのらち, 自生地で採取した 20 点（2017年 12 月に追 


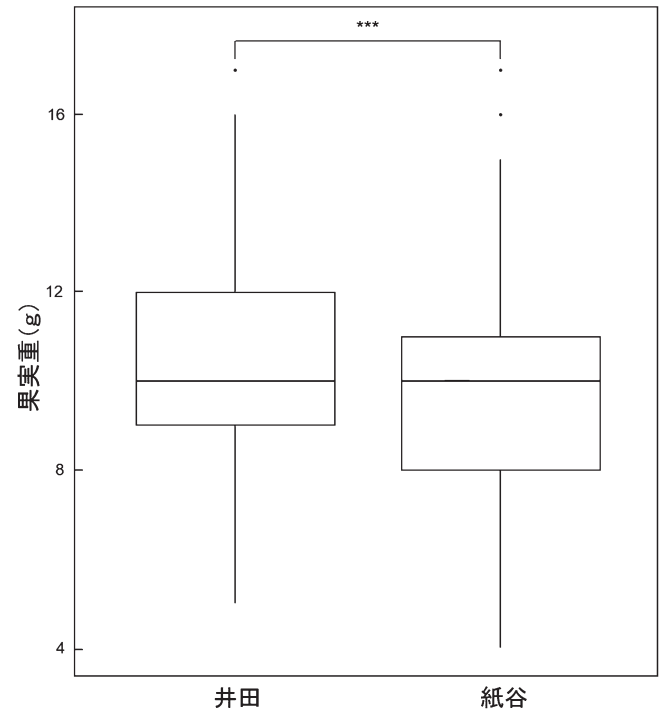

第4図 井田地区および紙谷地区で収集した果実の重量分布 紙谷地区の 24 樹および井田地区の 20 樹から収集した 456，打よび333 個の果実の重量の分布を示す（2地区の 果実の平均重はWilcoxonの順位和検定で $0.1 \%$ 水準で 有意差あり）

加採取した 1 点を含む）と，接木樹から採取した 4 点の計 24 点も，核打よびオルガネラの遺伝子型がタチバナ-Aの ものと完全に一致し，これらのいずれもタチバナ-A と結 論づけた。

収集したサンプルのらち, 紙谷地区の 2 点と井田地区の 2 点（らち 1 点は外周の接木樹）は既知の 3 種のタチバナ (タチバナ-A, タチバナ-B, タチバナ-C) のいずれとも遺伝 子型が一致しなかった. これら 4 点は調査した核抢よびオ ルガネラのマーカー遺伝子型が完全に一致し, クローン増 殖された同一個体と考光られた. マーカー遺伝子型を報告 されている在来カンキッ品種の遺伝子型と比較した結果, ナツミカン（C. natsudaidai Hayata）と全マーカーで一致し, オルガネラ遺伝子型もナッミカンのものと同じポメロ型
（C04；Shimizu ら，2016b）であったことから，これらはナ ツミカンであると結論された（第 5 表）.

\section{3. タチバナ-A 自然交雑種子の交雑胚の検証}

タチバナ-Aを種子親とする交雑肧の出現頻度を推定す る目的で，タチバナ-A 自然交雑種子の芽生えを対象に SSR マーカー分析を行った．分析には農研機構の傾斜地固 場で保存されているタチバナ-A樹を利用した。 供試樹と 隣接する他のカンキッ樹はすべてタチバナであり，授粉樹 となる可能性のあるナッミカン樹からは持よそ $6 \mathrm{~m}$ 離れ て，戸田自生地のタチバナの生育状況に近いものとなって いる. タチバナ-A は多胚性を有して扣り，採取した種子 の平均胚数は $10.95 \pm 2.42 （ \mathrm{n}=20 ）$ であった．2019年に播 種した完全種子の発芽率は 59.3\% $(\mathrm{N}=54)$, 発芽平均新 梢数は 1.72 で, 播種後 1 か月の新梢長は $53.2 \pm 24.8 \mathrm{~mm}$ と 大きな変異幅を示した。出現した 55 本の新梢から簡易法 で抽出したDNA はNA マーカー分析で良好な増幅を示 し，24種のSSR マーカー分析から，全個体がタチバナ-A と同じ遺伝子型を示したことから，これらはすべて珠心肧 実生と判定された。

\section{考察}

日本国内で発見されたカンキッ在来種の多くは，10 世 紀以前に日本国内に導入された少数の品種が交雑を繰り返 すことで 15 世紀以降に出現，発見されてきたことが近年 具体的に示されてきた（Shimizuら，2019）. タチバナはこ のらち最も古い時代から国内に存在したと考えられ，野生 状態で自生する複数の群落が長期間に渡って維持されてい る数少ないカンキッ種の一つである（Hirai ら，1990; 井手 ら，1989; 田中，1926）。 カンキッ類の多様性拡大過程を理 解することは, 利用価值の高い新品種の開発や，育種親と しての価值の高い品種を特定するなど, 在来品種の保全や カンキッ産業への貢献が期待される. 国内のタチバナが国 内各地に伝搬して定着した経緯の多くは不明だが，タチバ

第 5 表 収集したタチバナ樹の遺伝子型比較解析結果

\begin{tabular}{|c|c|c|c|c|}
\hline \multirow{2}{*}{ 収集地 } & \multirow{2}{*}{ 収集個体数 } & \multicolumn{3}{|c|}{ 遺伝子型分析結果 ${ }^{\mathrm{z}}$} \\
\hline & & 核遺伝子型 ${ }^{y}$ & オルガネラ遺伝子型 $\mathrm{x}$ & 該当個体数 \\
\hline \multirow[t]{3}{*}{ 紙谷地区 } & 実生 & タチバナ-A & タチバナ $(\mathrm{C} 14)^{\mathrm{w}}$ & 40 \\
\hline & & ナツミカン & ポメロ（C04） & 2 \\
\hline & 接木樹 $\quad 0$ & - & - & 0 \\
\hline \multirow[t]{4}{*}{ 井田地区 } & 実生 21 & タチバナ-A & タチバナ（C14） & 20 \\
\hline & & ナツミカン & ポメロ（C04） & 1 \\
\hline & 接木樹 & タチバナ-A & タチバナ $(\mathrm{C} 14)$ & 4 \\
\hline & & ナツミカン & ポメロ（C04） & 1 \\
\hline
\end{tabular}

z 核扣よびオルガネラ遺伝子型が Shimizu ら（2016b）の結果と完全に一致した品種名とオル ガネラ遺伝子型を示す

$\mathrm{y}$ 核遺伝子型分析には第 1 表に示した DNA マーカーを使用した

xオルガネラ遺伝子型分析には第 2 表に示したDNA マーカーを使用した

w括弧内の記号は Shimizu ら (2016b) のオルガネラ遺伝子型記号 
ナは多くのカンキッ品種と同様に多肧性を有することか ら，遺伝的に同質なクローンとして維持，伝搬されてきた ものとみなされてきたものの, 科学的に検証された例は皆 無であった. 一方, Hiraiら（1990）は国内各地で収集した 自生タチバナ系統間にアイソザイム多型を確認し, その後 の高精度 DNA マーカーを用いた核およびオルガネラゲノ ムの多型解析から, 国内のタチバナには3つの遺伝的に異 なる系統が存在し，それらが同一家系由来である可能性も 示された（Shimizu ら，2016b）。国内の自生地に打ける夕 チバナの多様性を明らかにし，長期間に渡り群落がどのよ らに維持されているのかを解明することは, 各系統の発生 と来歴を理解するための重要な知見をもたらすと期待さ れる.

本研究から, 静岡県沼津市戸田の 2 か所（紙谷地区, 井 田地区）に自生するタチバナ群落の全個体の核, およびオ ルガネラゲノム分析から, 各群落内にそれぞれ 2 個体のナ ツミカン樹が認められたものの, それ以外はすべてタチバ ナ-A型の個体であることが確認された. Hiraiら（1990） は紙谷地区, 井田地区で収集した 23 , および 11 点のタチ バナ個体のアイソザイム遺伝子型がすべて同一であったと 報告しており，今回得られた結果もその報告と一致した. 本研究で収集, 分析された個体数はHiraiら（1990）の分 析個体数よりも多いが, これは, 本研究では複数回の調査 を実施することで自生地内の全個体をほ涪網羅できたこと が主な理由と考えられる. 一方, 群落内には樹高 $1 \mathrm{~m}$ 以下 のタチバナの若木が複数認められたことから, 自生地内で は珠心肧実生由来の個体が定期的に供給されることで群落 内の個体数が維持されてきたことが強く示唆され, Hirai ら（1990）の調査後に新たな実生が発生したことで群落内 の個体数が増加したことも理由と考它られた．群落内には 花粉稔性の高いナツミカン樹が複数確認されたことから, 他殖もしくは自殖由来の個体の存在も期待されたが, 複数 のSSR マーカー分析から交雑個体は確認されなかった. ナツミカンは 1700 年頃に山口県で発見された偶発実生に 由来し（梶浦, 2008), 静岡県中部地域には1888 年に, 伊豆 半島南部には 1893 年に苗木が導入されて生産が開始され ている（静岡県柑橘販売農業協同組合連合会, 1959). 1936 年の柑橘生産統計では戸田でのナッミカンの栽培面積は 2 反（19.8 a）とあり（静岡県柑滳販売農業協同組合連合会, 1959), 80 年以上に渡りタチバナとナツミカンが近隣の地 区内で栽培されていたと考えられる. しかし今回の調査で 交雑個体は確認されなかったことから, タチバナ-Aの交 雑個体の獲得は容易ではないことが推測された。井手ら （1989）は戸田のタチバナのアイソザイム分析の結果から, この地区のタチバナでは有性的繁殖の割合が低いことを示 唆して抢り, 本研究に打ける現地調査結果と実生のDNA マーカー分析の結果からもその推論が裏付けられた.

伊豆地域には古くから野生のタチバナやクネンボ, ダイ ダイ，アマダイダイ，トウス，相模コウジなどのカンキッ
類があまり利用されることなく存在していたとされるが (静岡県柑橘販売農業協同組合連合会, 1959), これまでに 国内で発生したカンキッ品種の中にタチバナ-Aとこれら のカンキッとの交雑品種は確認されていない. ナッミカン 樹と隣接するタチバナ-A 樹の自然交雑種子由来の 55 個体 のDNA マーカー分析でも交雑個体は検出されなかったこ とや，これまでに見いだされたタチバナ 3 系統の後代品種 (ハナユ, ヒュウガナッ, ギリミカン，オウゴンカン）はす ベてタチバナを花粉親としていることから，タチバナを種 子親とする交雑胚は珠心肧よりも生育が劣るために交雑個 体が認められないのかもしれない，一方で，タチバナのこ のような特性は，種子繁殖により同一遺伝子型の個体を長 期間に渡り安定して維持するらえで有利に機能してきたと 考えられる. Katayamaら（2007）は国内のイワテヤマナシ 遺伝資源の DNA マーカー分析から幅広い多様性を観察し て扣り，長期間に渡りクローンとして維持されてきた戸田 のタチバナとは対照的である.

翻って，現在戸田で見られるタチバナの自生はいつ頃, どのようにして成立したものであろらか，現在までに同定 された 3 系統のタチバナが同祖系統であり，現在沼津市戸 田に自生するタチバナが，同地，もしくは近隣地域で未知 の親品種の交雑から生まれたものと仮定すると, 静岡県東 部ないしは東海地方で複数のタチバナ系統が自生すること が想定される．しかし今回戸田の 2 地区で確認されたもの はすべてタチバナ-Aであり，近隣を含め国内ではタチバ ナの親品種とみなされるものは同定されておらず，またこ れまでにタチバナ-A は静岡県と三重県で, タチバナ-Bは 愛知県, 三重県, 宮崎県で, タチバナ-Cは宮崎県で見い だされている（Shimizu ら，2016b）。井手ら（1989）が報告 したように，定期的に伐採される過程でタチバナ-A以外 の系統や交雑実生, 親品種が淘汰された可能性は否定でき ないものの, タチバナ系統の国内の分布から, タチバナ-A は国内の別の場所で生まれ，その後沼津市戸田に伝来した 可能性が高いと考えられる.

では, タチバナはどのよらにして戸田に到達して群落を 形成するに至ったのであろらか. 沼津市戸田は伊豆半島の 西北部に位置し，伊豆半島は静岡県東部から南に約 $50 \mathrm{~km}$ にわたって太平洋側に突き出し, 海岸部は温暖で降水量, 日射量ともに多い(年間降水量 $1976 \mathrm{~mm}$, 日平均気温 $16.6^{\circ} \mathrm{C}$, 日照時間 $2060.8 \mathrm{~h}$; 松崎 $2008 \sim 2018$ 年アメダス観 測值より)。静岡県東部は本州側のアムールプレートとオ ホーツクプレートが南からのフィリピン海プレートと接触 し，伊豆半島はその北端に位置して本州側にゆっくりと移 動している (小山, 2010). 現在の伊豆地域は今から 2,000 万〜 1,000 万年前にフィリピン海プレートの海底火山の活 動により隆起し始め，その後 200 万〜 100 万年前に本州側 と衝突を開始しつつ火山が出現して陸地を形成し，60万 年前頃に本州から突き出た現在の伊豆半島の原型が形作ら れたとされる。 戸田拉よび井田を含む伊豆半島の北西部で 
は, 現在の戸田港から修善寺をまたぐ大型火山である達磨 山が 100 万〜 50 万年前の噴火で作られ，それに接するよ らに井田火山, 大瀬崎火山が 80 万〜 40 万年前の噴火で出 現した. 箱根火山を除くすべての火山は 20 万年前に活動 を停止して和り, 現在見られる植物群はそれ以降に伝搬ま たは持ち込まれたものとなる。

現時点で紙谷打よび井田地区以外の近隣地域でタチバナ の自生は確認されて抢らず，なぜこの地域にのみタチバナ が生育しているのかといら点に疑問が残る. 戸田への伝来 を考えるらえで，ヒトが持ち込んだ可能性と，動物などヒ 卜以外のものにより持ち込まれた可能性の 2 つが想定され る. 前者に関して, 戸田にタチバナが持ち込まれた年代を 推測する手がかりは今のところ見つかっていないが, 紙谷 地区のものは時折伐採されることがあったものの野生状態 を維持して扔り，一方で井田地区に現在群生するタチバナ は人家に近く，人工的に移植されたものであると考えられ ている (Hirai ら， 1990; 井手ら，1989）. 静岡県東部の富士 市から沼津市にかけては浅間古墳 (4 世紀頃) や高尾山古 墳 (3 世紀頃), 神明塚古墳 (3世紀後半) など数多くの前 方後円墳や円墳, 定住跡が残されて招り, 伊豆半島の沼津 市井田には古墳時代後期（6世紀頃）のものとされる“井 田松江古墳群”が知られていることから，少なくとも 1,400 年前には既にヒトが戸田に定住していたと考えられる. 延 喜式（927 年）第 37 巻で述べられている典薬の生産地には 伊豆国に関する記述はないものの, 近隣の駿河國と相模国 の産物として「橘皮」が示されて扣り，既に 10 世紀には 静岡県中部から神奈川県に至る地域の特産物としてタチバ ナまたはその近縁種が朝廷に献上されていたと考光られ る。また，江戸時代には駿河国の5つの郡でタチバナの生 産が記録されている（静岡県柑橘販売農業協同組合連合 会, 1959). 伊豆半島北西部では紙谷地区自生地から西北 西に扎よそ $1.7 \mathrm{~km}$ 注どの山中にある通称「井田峠」にかつ てタチバナの古木が生育していた記録が残されて扣り（沼 津市教育委員会, 2014; 静岡県柑滳販売農業協同組合連合 会，1959），また戸田の南部，土肥との境は「タチバナ沢」 と呼ばれ（沼津市教育委員会, 2014), 現在の紙谷, 井田 地区以外の複数の地域にもかつてタチバナが点在していた ことをらかがわせる。これらの知見から，少なくとも 10 世紀には静岡県の東中部でタチバナが存在し, いつかの時 代に伊豆半島に持ち込まれたものの, その多くは消失し, 現在では戸田の紙谷地区と井田地区にのみ残るようになっ たのではないかと推測される。 日本国内で接木の技術が広 まったのは安土桃山時代以降とされて招り（梶浦，2008）, 10 世紀頃に戸田に伝来していたのであれば, 種子として 持ち込まれた可能性が高い。これとは別に，ヒト以外のも のが戸田にタチバナを伝搬した可能性も想定され, サルや シカ，果実食鳥などの動物による種子散布は多くの地域や 植物種で観察されている（佐藤, 2007; Wehncke, 2010). し かし現時点ではタチバナを含むカンキッ類の動物による長
距離の伝搬を裏付ける研究は乏しく, 推測の域を出ていな い. 一方で，戸田港御浜岬の諸口神社（1402 年再建）は 弟橘姫命を祭神としていること（諸口神社由緒より）から， 海上交通の要所としての戸田港に海路で直接タチバナがも たらされた可能性についても, 今後検討する価值がある.

以上のように，国内のタチバナ自生地の北限である静岡 市沼津市戸田の群落内の個体はすべて既知のタチバナ-A 型であると確認され，自殖，もしくは同一地域内で確認さ れたナツミカンとの交雑個体は見いだされなかったことか ら，戸田では多肧種子を介したクローン増殖により長期間 に渡ってタチバナ-Aの群落が維持されてきたと考えられ た。戸田にタチバナ-Aが持ち込まれた経緯は明らかでは ないが，かつて静岡県東部から神奈川県にかけてタチバナ が生産されてきた複数の記録が認められることから，伊豆 半島に人為的に持ち込まれて戸田に定着した可能性が考え られた。 戸田のタチバナ自生地は時折人手による管理が行 われてきたが，これは脆弱な生育基盤を安定化する効果が あったとも考えられ，今後国内のタチバナ自生地の保全を 図るらえでの参考となろら。

\section{摘 要}

タチバナ（Citrus tachibana（Makino）Tanaka）は奈良時 代以前から日本に存在していたと考兄られる在来カンキッ 種の1つで, 東海から九州にかけての太平洋岸側の山中に 複数のタチバナ自生地が存在する. 従来, タチバナは 1 種 とみなされてきたが，高精度 DNA マーカーによる解析か ら，少なくとも 3 つ遺伝的に異なる系統が存在すること が示されている. しかしこれまでの解析は各地域で採取さ れた一部の個体を対象として打り, 種としてのタチバナ, および自生地の群落内の遺伝的多様性に関する知見に之し かった. 我々はタチバナの群落内の遺伝的多様性を把握 し，将来の利用や保全に役立てる目的で，静岡県沼津市戸 田に自生するタチバナに注目し，自生地内の全個体（井田 地区 24 点, 紙屋地区 40 点）を収集した。核とオルガネラ の高精度 DNA マーカー分析の結果, 井田地区の 22 点と紙 谷地区の 38 点はすべて既知のタチバナ-A 型と遺伝子型が 完全に一致した。 また，井田抒よび紙谷地区の由来不明の カンキッ個体各 2 点は遺伝子型からナッミカンと判定され た. 群落内にはタチバナ-Aの自殖もしくはナッミカンと の交雑個体は確認されず, タチバナ-Aを種子親とする交 雑実生の獲得は困難であることが想定され，自然交雑実生 の DNA マーカー分析でも同様の結果が示された。群落内 に若木も確認されたことから，戸田タチバナ自生地では珠 心胚実生を介して無性的に個体が維持されてきたと推定さ れた。

謝 辞 本研究を実施するに当たり，タチバナ自生地内 に関する試料ならびに資料提供にご協力いただいた監物規 敏氏，野田重信氏，金田茂樹氏に感謝申し上げます。ま た，本稿の取りまとめに際してご助言いただいた吉武利文 
氏，ならびに試料の分析にご協力いただいた平野千秋氏， 大石尚子氏に感謝申し上げます。

\section{引用文献}

Hirai, M., S. Mitsue, K. Kita and I. Kajiura. 1990. A Survey and isozyme analysis of wild mandarin, tachibana (Citrus tachibana (Mak.) Tanaka) growing in Japan. J. Japan. Soc. Hort. Sci. 59: 1-7.

井手久登・武内和彦・梶浦一郎. 1989. 野生果樹自生地の 分布・構造と保全に関する応用植生学的研究. p. 84 . 昭和 62-63 年度科学研究費補助金一般研究 (B) 研究 成果報告書. 研究課題番号 (62480038).

梶浦一郎. 2008. 日本果物史年表. p. 31-35, 51. 養賢堂. 東京.

環境省. 2019. 環境省レッドリスト 2019.〈http://www.env. go.jp/nature/kisho/hozen/redlist/index.html $>$.

Katayama, H., S. Adachi, T. Yamamoto and C. Uematsu. 2007. A wide range of genetic diversity in pear (Pyrus ussuriensis var. aromatica) genetic resources from Iwate, Japan revealed by SSR and chloroplast DNA markers. Genet. Resour. Crop Evol. 54: 1573-1585.

小山真人. 2010 . 伊豆の大地の物語. p. 10-13. 静岡新聞 社. 静岡.

牧野富太郎. 1955. 牧野 日本植物図鑑. p. 337. 北隆館. 東京.

沼津市教育委員会. 2014. 戸田村史 民俗編一暮らしの伝 承一. p. 8 . 沼津.

佐藤重穂. 2007. 森林生態系における果実食鳥類群集の動 態と樹木種子の散布. 森林応用研究. 16: 37-42.

Shimizu, T., E. Kaminuma, K. Nonaka, T. Yoshioka, S. Goto, T. Matsumoto, Y. Katayose, T. Mochizuki, Y. Tanizawa, A. Toyoda, A. Fujiyama and Y. Nakamura. 2016a. A genomic approach to selecting robust and versatile SNP sets from next-generation sequencing data for genome-wide association study in citrus cultivars. Acta Hortic. 1135: 23-32.

Shimizu, T., A. Kitajima, K. Nonaka, T. Yoshioka, S. Ohta, S. Goto, E. Kaminuma and Y. Nakamura. 2019. A model for the domestication and diversification processes of modern citrus cultivars in Japan. Acta Hortic. 1320: 7-14.

Shimizu, T., A. Kitajima, K. Nonaka, T. Yoshioka, S. Ohta, S. Goto, A. Toyoda, A. Fujiyama, T. Mochizuki, H. Nagasaki, E. Kaminuma and Y. Nakamura. 2016b. Hybrid origins of citrus varieties inferred from DNA marker analysis of nuclear and organelle genomes. PLoS ONE 11: e0166969. $\langle$ https://doi.org/10.1371/journal.pone.0166969〉.

Shimizu, T. and K. Yano. 2011. A post-labeling method for multiplexed and multicolored genotyping analysis of SSR, indel and SNP markers in single tube with bar-coded split tag (BStag). BMC Research Notes 4: 161. 〈https://doi.org/ 10.1186/1756-0500-4-161>.

静岡県柑橘販売農業協同組合連合会. 1959. 静岡県柑橘 史. p. 114-195, 1015-1024. 清水.

Swingle, W. T. 1967. The botany of citrus and its wild relatives. p. 190-430. In: W. Reuther, H. J. Webber, L. D. Batchelor (eds.). The citrus industry. University of California Press, Berkeley, California.

田中長三郎. 1926. 日本領土の野生柑樀に就て. 九州帝國 大學農學部學藝雜誌. 2: 51-58.

Tanaka, T. 1931. The discovery of Citrus tachibana in Formosa, and its scientific and industrial significance. Studia Citrologica 5: 1-20.

Tanaka, T. 1954. Species problem in citrus: a critical study of wild and cultivated units of citrus, based upon field studies in their native homes (Revisio Aurantiacearum IX). p. 42-50. Japanese Society for the Promotion of Science, Tokyo.

Wehncke, E. V. 2010. Seed dispersal and conservation. p. 119124. In: M. D. Breed and J. Moore (eds.). Encyclopedia of animal behavior. Academic Press, Amsterdam.

Wu, G. A., J. Terol, V. Ibanez, A. López-García, E. PérezRomán, C. Borredá, C. Domingo, F. R. Tadeo, J. CarbonellCaballero, R. Alonso, F. Curk, D. Du, P. Ollitrault, M. L. Roose, J. Dopazo, F. G. Gmitter, D. S. Rokhsar and M. Talon. 2018. Genomics of the origin and evolution of Citrus. Nature 554: 311-316.

吉武利文. 2008. 橘の香り一古代日本人が愛した香りの植 物一. p. 13-21. フレグランスジャーナル. 東京. 